\title{
Tropical Spastic Para Paresis and Ayurveda
}

\author{
Dr Avinash Shankar ${ }^{1 *}$, Dr Amresh Shankar ${ }^{2}$, Dr Anuradha Shankar ${ }^{3}$ \\ ${ }^{I} M B B S(M G I M S) ; M D$ (Internal Medicine); DNB(E\&M); PhD, Postgraduate in Endocrinology \& Metabolism \\ (AIIMS Delhi), Chairman, National Institute of Health \& Research, Warisaliganj (Nawada) Bihar India \\ ${ }^{2}$ BAMS(BRABU); MHA, Director (Hon), Aarogyam Punarjeevan, Ram Bhawan, Ara Garden Road, Jagdeopath, \\ Baily Road, Patna 14, India \\ ${ }^{3}$ BAMS (BRABU), Ex Director, Centre for Indigenous Medicine \& Research, Senior Research Fellow, Regional \\ Institute of Ayurveda, Itanagar, Arunachal Pradesh, India
}

*Corresponding Author: Dr Avinash Shankar, PhD Postgraduate in Endocrinology \& Metabolism (AIIMS Delhi), Chairman, National Institute of Health \& Research, Warisaliganj (Nawada) Bihar India. Email: dravinashshankar@gmail.com

\begin{abstract}
Tropical spastic para paresis a disease of nervous system is caused by Human T lymphotrophic virus type I thus also known as HTLV-I associated myelopathy and common among female of age group 30-50 years in approximately 2-3\% of HTLV-1 affected person.

In spite advancement in diagnostic procedure i.e.-CTscan, MRI its treatment remain a challenge to ensure cure and better quality of life, thus a composite consisting a proven herbal neurogenic been evaluated
\end{abstract}

Object of Study: To assess the herbal neurogenic and immune boosting composite in ensuring clinical relief and improving quality of life in patients deterred from various medi centres without any relief.

Material \& Method: 63 diagnosed and already treated cases of Tropical spastic para paresis attending at Centre for Critical Care National Institute of Health \& Research Warisaliganj (Nawada)Bihar been selected, interrogated, examined clinically, assessed and analysed their previous investigation reports, therapeutics taken and their effect.

Irrespective of their clinical severity all patients were dvocated the prescribed regime and were followed for post therapy 2 years for which patients been given a follow up card to record the changes.

Result: $88.9 \%$ patients had grade I clinical response while rest $11.1 \%$ grade II without any untoward effect or any withdrawal during post therapy 2 years follow up.

Keywords: Tropical spastic para paresis, Human T lymphotrophic virus-type I, CT, MRI, herbal neurogenic

\section{INTRODUCTION}

Tropical spastic para paresis, a chronic and progressive clinical condition affecting Nervous system remained of obscure etiopathogenesis for long but now a days an important association of this condition been established between Human retrovirus (Human T cell lymphotropic virus type I) thus this condition is also termed as HTLV1 associated myelopathy (HAM).

As per W.H.O. estimate worldwide 10-20 million peoples are carrying HTLV1 and 5\% of it are affected with TSP of age group 30-50 years[1-10]

TSP is very common in Latin America, the Caribbean Basin, sub-Saharan Africa and Japan but these days incidence of this clinical state is increasing even in India.

Common presentation of the clinical condition is $-[11-14]$
- Gradual weakening and stiffening of lower extremity

- Raditing bakck pain down to legs

- Burning and pricking sensation (paraesthesia0

- Urinary and bowel function disturbances

- In male erectile dysfunction

- Inflammatory skin condition like dermatitis or psoriasis

- Rarely may present with eye inflammation, arthritis, and muscle inflammation

The common mode of transmission of this virus is through - [15-16]

- breastfeeding

- sharing infected needles during intravenous drug use

- sexual activity 
- blood transfusions

In spite of advancement in diagnostics (CT scan and MRI) and its established etiopathogenesis till date no established therapeutic regime ensured its reversal but only symptomatic relief, ie- alpha interferon, intravenous immunoglobulin, antiviral drugs and muscle relaxants Tizanidine

Signs and symptoms vary but may include slowly progressive weakness and spasticity of one or both legs, exaggerated reflexes, muscle contractions in the ankle, and lower back pain. Other features may include urinary incontinence and minor sensory changes, especially burning or prickling sensations and loss of vibration sense.

Considering the poor quality of life with present therapeutics a clinical study was planned to evaluate the clinical efficacy of proved neurogenic herbal composite with neuro modulator at National Institute of Health \& Research and Centre For Research in Indigenous Medicine.

\section{OBJECTIVE OF THE STUDY}

To evaluate he clinical efficacy and safety profile of herbal neurogenic with neuromodulator in TSP.

\begin{tabular}{|l|l|}
\hline Severity Grade & \multicolumn{1}{c|}{ Characteristics } \\
\hline Mild & Patients presenting with back pain, tingling and numbness in the leg \\
\hline Moderate & $\begin{array}{l}\text { Patient presenting with back pain, tingling numbness, tendency to fall Heaviness in the lower } \\
\text { extremity, leg weakness }\end{array}$ \\
\hline Severe & $\begin{array}{l}\text { Back pain, gait disturbance, stumbling, leg weakness, hyper reflexia, plantar Extensor, } \\
\text { overactive bladder, constipation and sexual dysfunction }\end{array}$ \\
\hline
\end{tabular}

Patients were investigated for hemoglobin concentration, total and differential leucocyte count, erythrocyte sedimentation rate (ESR),

\section{Material \& Methods}

Material: Patients of proved and treated cases of Tropical spastic Para paresis without any clinical response, attending at Centre for Critical Care, National Institute of Health \& Research were considered for evaluation of the herbal neurogenic constituting therapeutic regime.

Methods: Patients of spastic para paresis diagnosed by myelogram, computerized tomography(CT) and magnetic resonance imaging (MRI) been interrogated thoroughly for the onset, duration and evolution of the disease, Family history of neurological illness, history of extramarital sexual exposure, abortion, blood transfusions, dietary with emphasis on strict vegetarianism, Lathyrus sativus, Socio-economic status, housing, sanitary conditions, treatment taken and their response. A detailed general examination and a meticulous neurological

Based on clinical presentation patients were classified as assessment were done.

\begin{tabular}{|l|l|l|}
\hline Disturbances & Symptoms & Signs \\
\hline Motor & $\begin{array}{l}\text { Gait disturbance, tendency to fall } \\
\text { Stumbling and leg weakness }\end{array}$ & $\begin{array}{l}\text { Spastic para paresis, weakness hyperreflexia lower } \\
\text { limb, clonus }\end{array}$ \\
\hline Sensory & $\begin{array}{l}\text { Pain numbness at lumbar level And } \\
\text { backache }\end{array}$ & $\begin{array}{l}\text { Plantar extensor feet paresthesia, loss of light touch } \\
\text { sensory level at lower thoracic level }\end{array}$ \\
\hline Autonomic & $\begin{array}{l}\text { urinary dysfunction, constipation } \\
\text { Sexual dysfunction }\end{array}$ & $\begin{array}{l}\text { neurogenic or overactive bladder diminished } \\
\text { peristalsis Erectile dysfunction }\end{array}$ \\
\hline
\end{tabular}

All patients underwent conventional myelography CT and MRI scans. The serum samples of all the patients were tested for HTLV1 antibodies by the serodia technique. peripheral smear, fasting and postprandial blood sugar, renal and liver function tests, and serological test for syphilis. Common presentation of TSP can be summarized as -

Inj Calcium gluconate 1amp every 15th day intravenous very slow

Inj Methyl cobalamine +Pyridoxin +Niacinamide +Pantothenic acid + Betamethasone every week

Inj Self blood + Betamethasone $2 \mathrm{mg}$ every 10 th day intramuscular

Cap Vitamin D3 60 K every week orally

Syrup NEUROVIT $10 \mathrm{ml}$ every 12 hours /Cap NEUROVIT 1 cap every 12 hours

Active and passive exercise of the extremity

Diet: High Protein vegetarian diet

Herbal composite NEUROVIT Syr or Capsule constitutes - Cap 500mg or Syr. 5ml constitutes
All patients presenting with this crippling disease were advised and administered the following therapeutic regime after due awareness counselling and encouragement - 
monnieri (leaf), Convolvulus pluricaulis (flower), Cassia acutifolia (seed)

Patients were assessed for improvement in tone and power of the muscle, tingling and numbness, gait, and autonomic function (passage of stool and urine) for which patients were given a follow up card to mention date of achievement and any untoward manifestation experienced. Patients were advised to visit the center on any unusual manifestation or contact on helpline for needful redresses.

To adjudge the safety profile of the regime practiced basic bio parameters were repeated every month for first three month and then every 3 months.

Based on the clinical outcome and safety profile therapeutic response was graded as -

\begin{tabular}{|l|l|}
\hline Clinical Grade & Characteristics \\
\hline Grade I & $\begin{array}{l}\text { Complete recovery of power and } \\
\text { tone without any Residual } \\
\text { neurological deficit and } \\
\text { adversity }\end{array}$ \\
\hline Grade II & $\begin{array}{l}\text { Improvement in power and tone } \\
\text { with residual paresis and sensory } \\
\text { deficit without any adversity }\end{array}$ \\
\hline Grade III & No alteration in status \\
\hline
\end{tabular}

\section{RESUlT}

63 identified, diagnosed and treated Patients of Tropical spastic para paresis considered for study were of age group 30-50 years and out of them majority (30/63) were of age group 30-35 years with female dominance (Table-1, Figure 1) and all were from rural background and community representation was (figure 2)

Table1. Shows distribution of patients as per age \& sex

\begin{tabular}{|l|l|l|l|}
\hline Age Group & \multicolumn{3}{|l|}{ Number of Patients } \\
\hline (In years) & Male & Female & Total \\
\hline $30-35$ & 02 & 28 & 30 \\
\hline $35-40$ & 04 & 12 & 16 \\
\hline $40-45$ & - & 06 & 06 \\
\hline $45-50$ & - & 11 & 11 \\
\hline
\end{tabular}

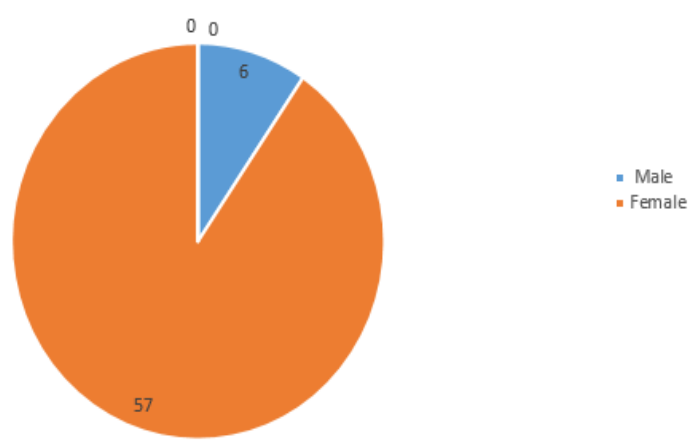

Figure1. Pie diagram showing Male: Female composition

ARC Journal of Clinical Case Reports
Distribution as per community

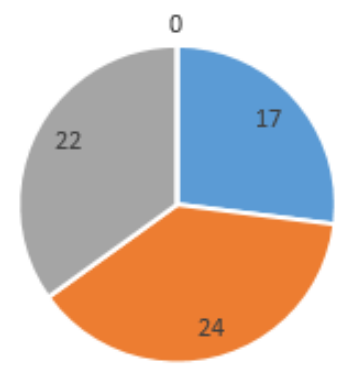

- Dalit " Muslim $n$ Other

Figure2. Pie diagram showing distribution of patients as per community

Out of all majority were non vegetarian and non had any history of taking Lathyrus sativus. (figure -3)

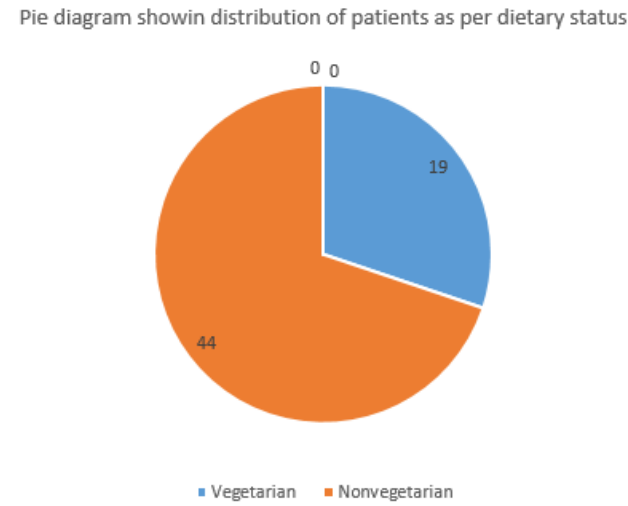

Figure3. Pie Diagram Showing Dietary Status

The age of onset of clinical presentation varied from 20-40 years and duration of illness from 1 year to 12 years (Figure-4)

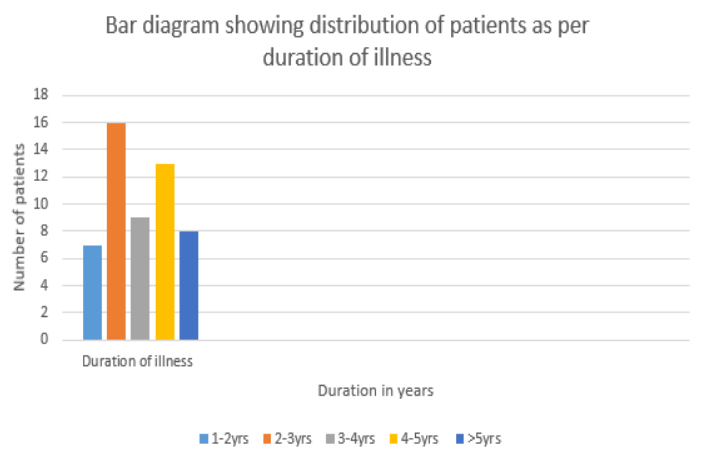

Figure4. Bar Diagram Showing Distribution of Patients as Per Duration of Illness

Symptoms at the onset were difficulty in walking, stiffness of legs, back pain, weakness of legs, leg pain and urinary discomfort (Table-) while presenting presentation at our center were disturbed gait, leg stiffness, back pain, leg pain urinary discomfort, urinary retention, tingling and numbness, erectile deficiency in male cases. (Table -2) 
Table2. Showing Distribution of Patients as Per Their Clinical Presentation

\begin{tabular}{|l|l|}
\hline Clinical Presentation & Number of Patients \\
\hline Difficulty in walking & 63 \\
\hline Leg Stiffness & 63 \\
\hline Back Pain & 43 \\
\hline Weakness of the legs & 63 \\
\hline Leg Pain & 63 \\
\hline Tingling and Numbness & 63 \\
\hline Gait Disturbance & 50 \\
\hline Urinary Discomfort & 50 \\
\hline Sexual Weakness & 06 \\
\hline $\begin{array}{l}\text { History of surgery, abortion } \\
\text { and blood transfusion }\end{array}$ & None \\
\hline
\end{tabular}

No history of blood transfusion, abortion, delivery or surgery prior to onset of the disease but serum samples revealed positive for HTLV-1 in 49 cases out of 63. In addition all the bio parameters (Hepatic, hematological and renal profile remain normal) (Figure -5)

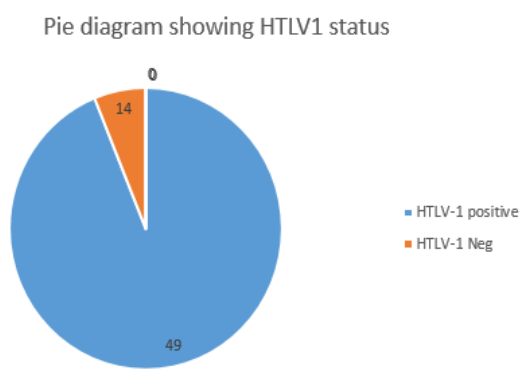

Figure5. Pie Diagram Showing HTLV-I Status of the Patients

No patients were positive for Tuberculosis, any sexually transmitted disease, CT and MRI also shows normal in all the cases, Out of 63 patients 13 were of moderate and 50 were of severe status (Figure-6)

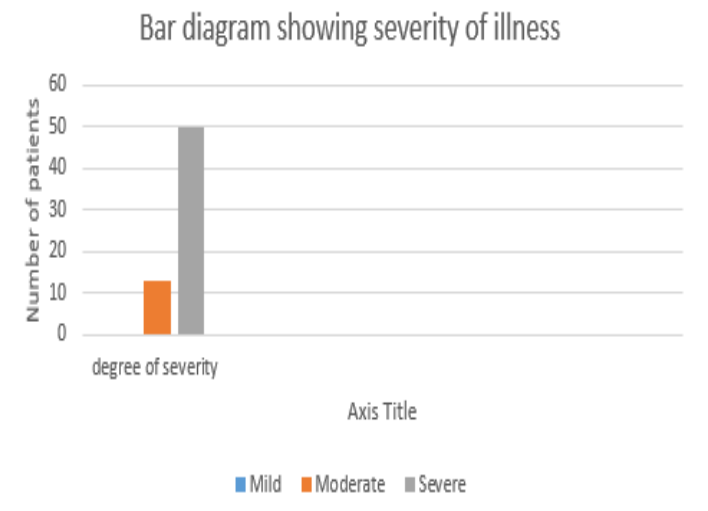

Figure6. Bar Diagram Sowing Clinical Severity

Patients had taken treatment with $\alpha$ interferon, muscle relaxants, neuro vitamin supplementation at various medicare centers without any positive therapeutic outcome. (Table-3)

ARC Journal of Clinical Case Reports
Table3. Showing Treatments Taken in Past

\begin{tabular}{|l|l|}
\hline Therapeutics Taken & Number of Patients \\
\hline Alpha Interferon & 43 \\
\hline Antiviral Drug & 49 \\
\hline Muscle Relaxants & 63 \\
\hline Neurovitamin Supplement & 63 \\
\hline Active \& Passive Exercise & 63 \\
\hline
\end{tabular}

Symptomatic relief started from $4^{\text {th }}$ week of therapy and by $24^{\text {th }}$ week all had symptomatic relief (Figure -7)

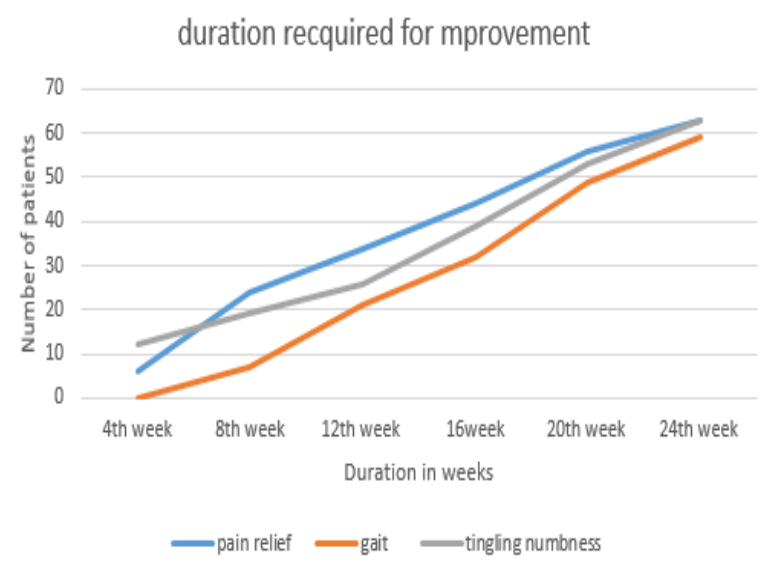

Figure7. Graph Showing Duration Required for Improvement in Presentation

The minimum and maximum duration of therapy required for complete reversal of clinical presentation (both symptom \& sign) is 9 months and 2 years respectively

Out of all 56 patients achieved Grade I clinical improvement and 7 Grade II(Figure-8)

\section{Bar diagram showing therapeutic outcome}

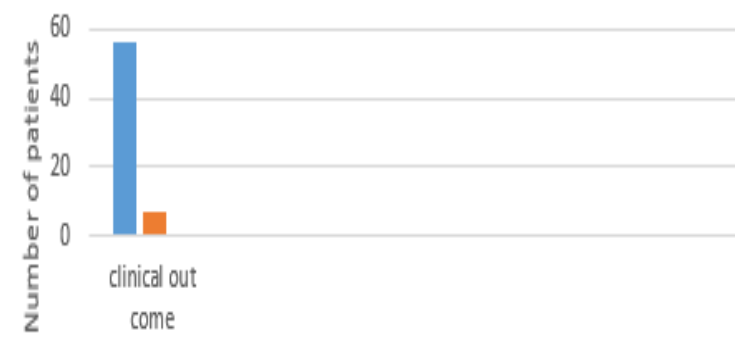

Clinical grades

-Grade | I Grade || |Grade |||

Figure8. Bar Diagram Showing Grades of Clinical Response

No patients shown any adversity, recurrence of presentation or any alteration in bio parameters in 2 years of post therapy follow up. (Table -4 )

Page | 14 
Table4. Showing Outcome of the Study

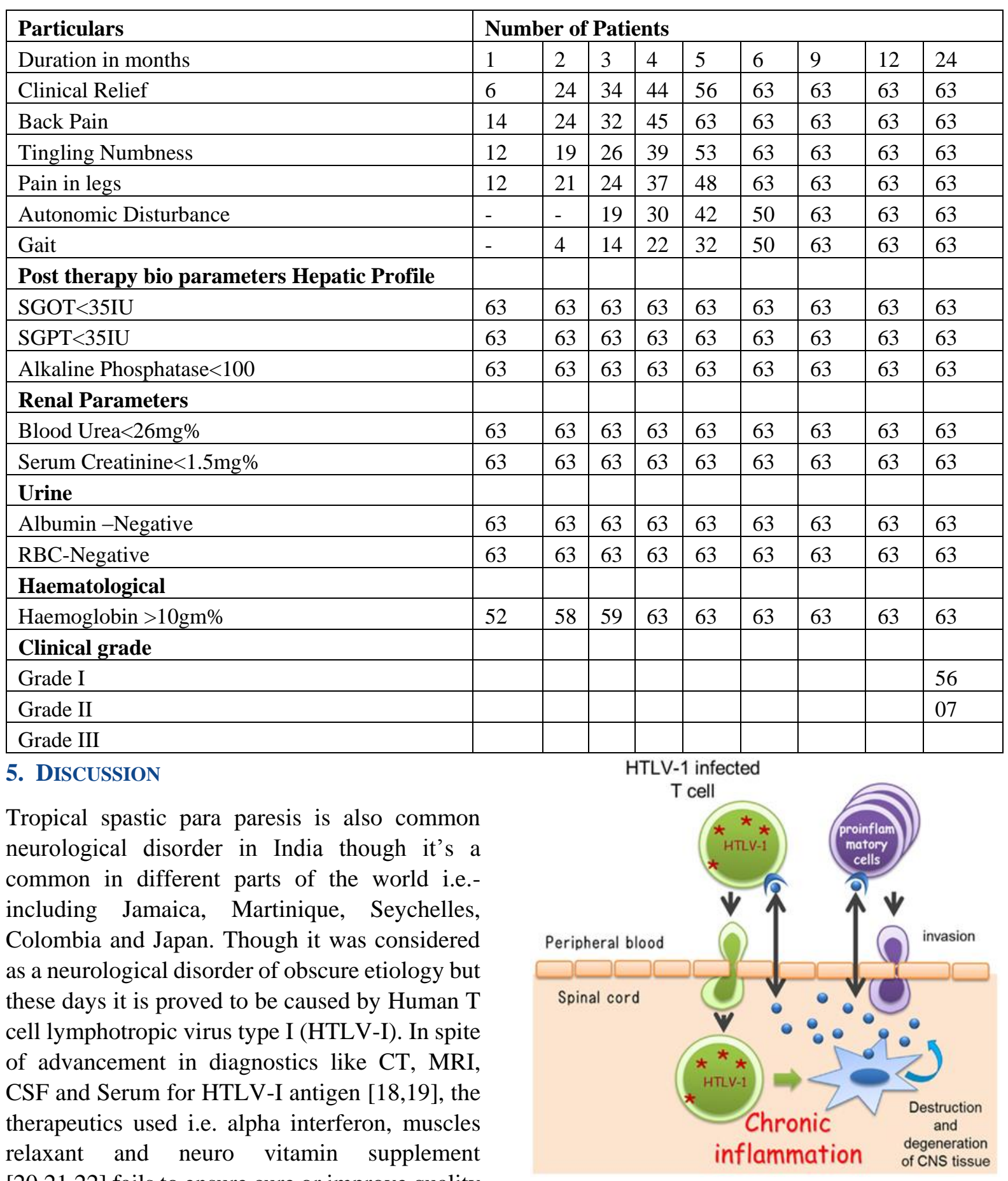
$[20,21,22]$ fails to ensure cure or improve quality of life except transient symptomatic relief.

Clinical supermacy in term of marked improvement in pain, sensation and gait of the already treated patients with other regime and achieving Grade I clinical response in $88.9 \%$ patients and Grade II in rest $11.1 \%$. No patients had any withdrawal or drug adversity in 2 years post therapy follow up.

This clinical efficacy can be explained asConsidering its pathogenesis and caused due to HTLV-I infected T cells

Self- blood with Betamethasone intramuscular induces antibody formation against the released toxin and ensure their neutralization while betamethasone acting as anti-inflammatory reduces neural edema synergized by Intravenous Calcium administration whose inclusion of one mole exit 2 mole of Sodium acting on Sodium potassium ATPase pump and facilitate decrease in neural edema and calcium ion improves neural conduction.

Methyl cobalamine, pyridoxine, Niacin and pantothenic acid support neural cells in its normal neural conduction and Neurovit a herbal 
composite by its neurogenic activity helps in restoration of neural viability and vitality which combinely ensure relief in pain, neuropathic manifestation, gait and autonomic function and provide better quality of life to all

\section{CONClusion}

Present regime constituting Calcium gluconate intravenous, Methyl cobalamine +Pyridoxin+ Niacin intravenous, Self -blood (2ml) and Betamethasone 2mg intramuscular, cap Cholecalciferol 60K, Syrup Herbal neurotonic (Neurovit) proves worth in management of Tropical spastic para paresis even in chronic and long term treated cases.

\section{REFERENCES}

[1] World Health Organization (WHO). (1989). Human T lymphotropic virus type 1, HTLV Wkly. Epidemiol. Rec. 64, 382-383.

[2] Orland, J. R., Engstrom, J., Fridey, J., Sacher, R. A., Smith, J. W., Nass, C., et al. (2003). Prevalence and clinical features of HTLV neurologic disease in the HTLV outcomes study. Neurology 61, 1588-1594.Pubmed Abstract | Pubmed Full Text $\mid$ CrossRef Full Text

[3] Blattner, W. A., and Gallo, R. C. (1985). Epidemiology of human retroviruses. Leuk. Res. 9, 697-698.Pubmed Abstract| Pubmed Full Text | CrossRef Full Text

[4] Oomman A, Madhusoodanan M. Tropical spastic paraparesis in Kerala, South India. Neurol India 2003; 51: 493-6 Year: 2003 | Volume: 51 | Issue: 4 | Page: 493-496

[5] Roman GC. The neuroepidemiology of tropical spastic paraparesis. Ann Neurol 1988;23:113-20

[6] Arango C, Concho M, Zaninovic V, Biojor, Borrero I, Rodgers, et al. Epidemiology of tropical spastic paraparesis in Colombia and associated HTLV-1 infection. Ann Neurol 1988;23:161-5.

[7] Richardson JH, Newell AL, Newman PK, Mani KS, Rangan G, Dalgleish AG. HTLV-1 and neurological disease in South India. Lancet 1989;I:1079

[8] Gessain A, Barin F, Vernant JC, Gout O, Calendar A, De-The G. Antibodies to human Tlymphotropic virus type I in patients with tropical spastic paraparesis. Lancet 1985;ii:40710.

[9] Rubin M. Tropical Spastic Paraparesis/HTLV1-Associated Myelopathy (TSP/HAM). Merck Manual. October, 2016; http://www.Merck manuals.com/professional/neurologic-disorders /spinal-cord-disorders/ tropical-spastic-parapare sis-htlv-1\%E 2\%80\%93associated-myelopathytsp-ham
[10] Tropical Spastic Paraparesis Information Page. National Institute of Neurological Disorders and Stroke. https://www.ninds.nih. gov/Disorders/All-Disorders/Tropical-SpasticParaparesis-Information-Page. Accessed 7/12/ 2017

[11] Iwasaki,Y (1990) Pathology of Chronic myelopathy associated with HTLV-Iinfection (HAM/TSP), J.Neurolo.Sci.96,103-123,Pubmed

[12] Izumo,S, Umehara ,F., and Osame,M (2000), HTLV-1 associated myelopathy, Neuropathology 20,565-568 Pubmed

[13] Osame, M. (2002). Pathological mechanisms of human T-cell lymphotropic virus type Iassociated myelopathy (HAM/TSP). J. Neurovirol. 8, 359-364.Pubmed Abstract | Pubmed Full Text $\mid$ CrossRef Full Text

[14] Lezin, A., Olindo, S., Oliere, S., Varrin-Doyer, M., Marlin, R., Cabre, P., et al. (2005). Human T lymphotropic virus type I (HTLV-I) proviral load in cerebrospinal fluid: a new criterion for the diagnosis of HTLV-I-associated myelopathy/tropical spastic paraparesis? J. Infect. Dis. 191, 1830-1834.Pubmed Abstract | Pubmed Full Text | CrossRef Full Text

[15] Matsuzaki, T., Nakagawa, M., Nagai, M., Usuku, K., Higuchi, I., Arimura, K., et al. (2001). HTLV-I proviral load correlates with progression of motor disability in HAM/TSP: analysis of $239 \mathrm{HAM} / \mathrm{TSP}$ patients including 64 patients followed up for 10 years. J. Neurovirol. 7, 228-234.Pubmed Abstract|Pubmed Full Text | CrossRef Full Text

[16] De Castro-Costa, C. M., Araújo, A. Q., Barreto, M. M., Takayanagui, O. M., Sohler, M. P., da Silva, E. L., et al. (2006). Proposal for diagnostic criteria of tropical spastic paraparesis/HTLV-Iassociated myelopathy (TSP/HAM). AIDS Res. Hum. Retroviruses 22, 931-935.Pubmed Abstract|Pubmed Full Text $\mid$ CrossRef Full Text

[17] Bagnato, F., Butman, J. A., Mora, C. A., Gupta, S., Yamano, Y., Tasciyan, T. A., et al. (2005). Conventional magnetic resonance imaging features in patients with tropical spastic paraparesis. J. Neurovirol. 11, 525-534.Pubmed Abstract|Pubmed Full Text |CrossRef Full Text

[18] Scadden DT, Freedman AR, Robertson P. Human T-lymphotropic virus type I: Disease associations, diagnosis, and treatment. UpToDate. Waltham, MA: UpToDate; February 16, 2016; http://www.uptodate.com/contents/ human-t-lymphotropic-virus-type-i-diseaseassociations-diagnosis-and-treatment

[19] Sandbrink F. Tropical Myeloneuropathies Treatment \& Management. Medscape Reference. January, 2015; http://emedicine.medscape. com/ article/1166055-treatment

[20] Arimura, K., Nakagawa, M., Izumo, S., Usuku, K., Itoyama, Y., Kira, J., et al. (2007). Safety and efficacy of interferon- $\alpha$ in 167 patients with 
human T-cell lymphotropic virus type 1associated myelopathy. J. Neurovirol. 13, 364372. Pubmed Abstract | Pubmed Full Text | CrossRef Full Text

[21] Croda, M. G., de Oliveira, A. C., Vergara, M. P., Bonasser, F., Smid, J., Duarte, A. J., et al. (2008). Corticosteroid therapy in TSP/HAM patients: the results from a 10 years open cohort.
J. Neurol. Sci. 269, 133-137.Pubmed Abstract | Pubmed Full Text | CrossRef Full Text

[22] Taylor, G. P., Goon, P., Furukawa, Y., Green, H., Barfield, A., Mosley, A., et al. (2006). Zidovudine plus lamivudine in human Tlymphotropic virus type-l-associated myelopathy: a randomised trial. Retrovirology 3, 63.Pubmed Abstract | Pubmed Full Text | CrossRef Full Text

Citation: Dr Avinash Shankar, Dr Amresh Shankar, Dr Anuradha Shankar, Tropical Spastic Para Paresis and Ayurveda. ARC Journal of Clinical Case Reports. 2019; 5(2): 11-17. doi:dx.doi.org/ 10.20431/2455-9806.0502 004.

Copyright: () 2019 Authors. This is an open-access article distributed under the terms of the Creative Commons Attribution License, which permits unrestricted use, distribution, and reproduction in any medium, provided the original author and source are credited. 